Chapman University

Chapman University Digital Commons

Education Faculty Articles and Research

Attallah College of Educational Studies

$2-22-2019$

\title{
Through Community Eyes: The Transition of International Organizations from Community Aid to Development in Postconflict Sierra Leone
}

Whitney McIntyre Miller

Chapman University, wmcintyr@chapman.edu

Follow this and additional works at: https://digitalcommons.chapman.edu/education_articles

Part of the African Studies Commons, Development Studies Commons, Infrastructure

Commons, International Relations Commons, Other Political Science Commons, Peace and

Conflict Studies Commons, and the Social Policy Commons

\section{Recommended Citation}

McIntyre Miller, W. (2019). Through community eyes: the transition of international organizations from community aid to development in postconflict Sierra Leone. Journal of Community Practice, 27(1), 60-77. https://doi.org/10.1080/

10705422.2019 .1580654 


\section{Through Community Eyes: The Transition of International Organizations from Community Aid to Development in Postconflict Sierra Leone}

\section{Comments}

This is an Accepted Manuscript of an article published in Journal of Community Practice, volume 27, issue 1, in 2019, available online at DOI: 10.1080/10705422.2019.1580654. It may differ slightly from the final version of record.

\section{Copyright}

Taylor \& Francis 


\section{Through community eyes: The transition of international organizations from community aid to development in postconflict Sierra Leone}

Sierra Leone experienced an 11-year civil war, brutalizing its people and destroying its communities. With the cessation of violence, international organizations helped to secure peace, deliver aid and supplies, and afterward, assist with development projects. This grounded theory study, which aims to understand the role these organizations played from the viewpoint of community members in two communities, posits that community members' regard of international organizations lessened as their efforts transitioned from securing the peace and relief efforts to aid for development. Highlighted are the successes and challenges of this work and a broad discussion of implications and recommendations.

Key Words: Sierra Leone, community, development, international organizations, postconflict 
Running Head: COMMUNITY TRANSITION IN SIERRA LEONE

\section{Through community eyes: The transition of international organizations from community aid to development in postconflict Sierra Leone}

Sierra Leone experienced a brutal 11-year civil war that destroyed communities and infrastructure. With the cessation of violence in 2002, many international organizations helped to secure peace in the communities, deliver aid and supplies, and assist with national and community-based development projects. With such an extensive in-country presence and postconflict role, this study critically examines the benefits and challenges of international organizations’ postconflict community development efforts in Sierra Leone as experienced by two communities in Sierra Leone’s Northern provinces. This study posits that community members’ regard for international organizations lessens as their efforts transition from securing the peace and relief efforts to aid for development. Discussion herein includes local views of the successes and challenges of the work of these international organizations, offers some implications and recommendations for international organizations and those communities who utilize their assistance, and provides overall lessons for communities in other contexts.

\section{Overview of Sierra Leone conflict}

Sierra Leone is a small country on the western coast of Africa that freed slaves settled in 1787, the British colonized in 1808, and achieved independence on April 27, 1961 after decades of political dissent (Alie, 1990; Keen, 2005; U.S. Department of State, 2008). The years following saw turmoil, corruption, and upheaval, with a series of leaders and military coups creating an environment ripe for unrest (Alie, 1990; Keen, 2005). In 1991, the civil conflict began when the rebel group the Revolutionary United Front (RUF) entered into Sierra Leone and burned villages, amputated limbs, and raped civilians, all under the guise of liberating people from corruption and oppression. In actuality, however, the rebels were fighting for complete economic and political control (Abraham, 2001; Carver, 1997; Keen, 2005; U.S. Department of 
Running Head: COMMUNITY TRANSITION IN SIERRA LEONE

State, 2008). Although some joined for the goals and ideals of the RUF, children, sometimes as young as eight years old, were conscripted into the rebel forces and drugged to reduce their fear around executing much of the conflict’s violence (Binns \& Maconachie, 2005; Carver, 1997).

In addition to the civilian violence, the civil conflict consisted of military coups and failed peace attempts. With peace finally reached in 2002, approximately 50,000 to 70,000 of the 4.7million citizens had been killed (Masin-Peters, 2003; Pham, 2006). In addition, an estimated 2.6 million people became refugees in neighboring and other countries, and another 1.2 million became internally displaced--leaving behind their family, possessions, and homes (Carver, 1997; King, 2005, Masin-Peters, 2003; Pham, 2006). Of those who stayed, hundreds of thousands had limbs amputated or were in other ways maimed (Pham, 2006).

The period of civil conflict saw the destruction of the country's infrastructure, the disruption of economic activities, an increase in poverty, and many of the young men and women in the country forcefully conscripted or raped (Binns \& Maconachie, 2005; Pham, 2006). The status of Sierra Leone at the end of the conflict was grim, solidifying it as one of the least developed countries in the world (U.S. Department of State, 2008). Particularly affected were the local Sierra Leonean communities, which faced major challenges such as resettling internally displaced persons and refugees; creating a space to process the violence experienced and exposure to new ideas; building infrastructure, including roads, water systems, electricity, health care, schools, and other necessities; and creating a stable economy. This context is where the involvement of international organizations became essential to Sierra Leone and set the stage for this research.

\section{Definition of terms}


Running Head: COMMUNITY TRANSITION IN SIERRA LEONE

For the purposes herein, the definition of international organizations refers to those organizations whose headquarters are located in a country outside of Sierra Leone. These are both bilateral and multilateral organizations; those that receive funding from one country or multiple countries, respectively (Mlambo, Kamara, \& Nyende, 2009). International organizations provide aid to Sierra Leone in terms of financing and/or programming to assist in postconflict community development. Inspired by Keen’s (2008) removal of re- words, such as redevelopment, to place focus on Sierra Leone moving forward from the conflict not going back, I use the term postconflict, without a hyphen, to define this period of time as its own. This term is also used by multiple authors, including Hutchful (2012), Khadiagala (2012), and Olonisakin (2008) who are cited in this article. Postconflict community development reflects the efforts taken in local, geographically defined communities to move forward toward sustainable peace after the conflict. While there were other efforts to engage in community development in postconflict Sierra Leone, including local and national efforts, the postconflict community development efforts discussed in this paper are those supported in some way by international organizations.

\section{Review of relevant literature}

In postconflict countries, international organizations often provide aid, resources, and policy advice at both local and national levels (Chenge, 2002; Mlambo et. al, 2009, Rogers, 2006; UNDP, 2006 USAID, n.d.). These international organizations, particularly bilateral ones, tend to be the first responders after conflict, as they often already have the resources, expertise, and preparation needed (Mlambo, et. al., 2009). In the case of Sierra Leone, various international organizations played roles in providing assistance, and pledged US\$640 million for postconflict 
Running Head: COMMUNITY TRANSITION IN SIERRA LEONE

development (Fanthorpe, 2003; Rogers, 2006, World Bank, n.d.). The World Bank alone pledged an additional \$190.5 million, and gave post-war debt relief of \$600 million (World Bank, n.d.). Reports of funding in Sierra Leone range from \$2.5 to \$16.4 billion (Freeman, 2008; Hanlon, 2005; M’Cormack-Hale, 2010).

Much of the funds went to securing the peace, an endeavor by the United Kingdom, the Sierra Leonean government, and the United Nations Assistance Mission in Sierra Leone (UNAMSIL) that was considered robust and successful in that it brought security to the people and communities (Curran \& Woodhouse, 2007; Kaplan, 2013). These interventions were seen largely as positive associated with high quality troops and collaboration (Jackson, 2005). It is important to note, however, that Kaplan (2013) and Hutchful (2012) both offer criticism of this success, illustrating that international intervention was done with a Western lens and goals and limited national ownership.

After the cessation of violence, the international assistance funds, and even part of the UNAMSIL mission, switched to development. This switch occurred in hopes of restarting the economy and mending social infrastructure, including developing agriculture, building health care and education systems, creating youth employment, facilitating reconciliation, reconstruction of the rule of law and judicial system, and developing community structures (Bah, 2013; Chenge, 2002; Curran \& Woodhouse, 2007; Jackson, 2005; Mlambo et. al., 2009; Rogers, 2006; Sriram, 2011; UNDP, 2006 USAID, n.d.). A switch, which required a focus on women (Curran \&Woodhouse, 2007), took too long (Bah, 2013) and was furthered challenged, particularly economically, by the 2013-2016 Ebola epidemic (Karns, Mingst, \& Stiles, 2015). As recently as 2015, approximately half of the government budget was still coming from foreign assistance, with international organizations assuming a central role, although government 
Running Head: COMMUNITY TRANSITION IN SIERRA LEONE

committees were now involved in monitoring and regulating these funds (Baker \& May, 2006; Fanthorpe, 2003; Freeman, 2008; Olaleye \& Becker, 2005; United Nations Development Program, 2018).

Additional challenges to the assistance of international organizations include those that follow. Aid from international organizations is often unsustainable, as it tends to come at the end of a conflict and then wane after a time, and can often lead to contradictory efforts (Khadiagala, 2012; Mlambo, et. al., 2009; USAID, n.d.). This aid can also undermine and marginalize the development efforts of the state, as international organizations can provide more than the national governments (M’Cormack-Hale, 2013). International organizations tend to have a onesize fits all approach, which may not be culturally relevant, take into consideration community needs, or trust local affiliates (Fanthorpe, 2003; Sriram, 2011; USAID \& UNDP, 2000) and may bring a Western understanding of wages to a social fabric that focuses on community rather than individual wealth (Bolten, 2014). International organizations can lack democratic frameworks and transparency, not focus enough of the social and environmental impact of their work (Callaway, 2005), and can, in some cases, even be fraudulent, leaving communities with issues of mistrust and disillusionment (Manning, 2009) or abusive (Karns, Mingst, \& Stiles, 2015). Efforts by these organizations may focus only on one part of the population rather than all community members, particularly ignoring women (Hutchful, 2012). Such was the case with the UN and USAID’s Disarmament, Demobilization, and Reintegration (DDR) program (Kaplan, 2013; USAID, n.d,), which focused solely on ex-combatants and had trouble truly reintegrating them (Bah, 2012; Olonisakin, 2008); in some cases, training ex-combatants for jobs that were not those needed most in the community (Freeman, 2008). 
Running Head: COMMUNITY TRANSITION IN SIERRA LEONE

These challenges are particularly important as postconflict countries often lack selfconfidence, and therefore rely heavily on these international organizations for support (Burde, 2004; Glentworth, 2002). Therefore, international organizations’ programs must place a greater focus on building trust, connecting to local needs, and going beyond rhetoric about local ownership in order to tap into local traditions and share control with the local community to build sustainable peace and local capacity (AFREX, 2007; Bah, 2013; Bolten, 2014; Chenge, 2002; Cubitt, 2012; Fanthorpe, 2003; Leff, 2008; M’Cormack-Hale, 2010; 2013; UNDP, 2006, a relationship that did develop somewhat overtime (Hutchful, 2012). When programs move slowly and ensure needs are met, relationships and commitment are built, as was the case with the World Bank’s (n.d.) Community Driven Development program. The relationship between international organizations and communities is still an important and relevant conversation, as individuals who are more connected to, and participating in, international organizational projects are more politically and civically engaged (M’Cormack-Hale, 2010), which can increase capacity for development.

Despite over fifteen years of international development aid coming into Sierra Leone, the literature is still limited in exploring the relationship between international organizations and postconflict development in Sierra Leone, particularly from the community perspective. Rather, studies often focus on the perspective of international organizations and staffers. To that end, the purpose of the research was to understand the local, community perspective of the role of international organizations in postconflict community development.

\section{Study methods}

This study builds on Fanthorpe’s (2003; 2004; 2005) and M’Cormack-Hale’s (2010; 2013) fieldwork, but explains the efforts of international organizations by exploring community-based 
Running Head: COMMUNITY TRANSITION IN SIERRA LEONE

perspectives exclusively, and is part of a larger study on the multidimensional aspects of postconflict community development in Sierra Leone (McIntyre Miller, 2010; 2012). With limited scholarship on the Sierra Leone postconflict community development experience, particularly from a community perspective, this study utilized a constructivist grounded theory approach (Charmaz, 2005). Constructivist grounded theory allows the views and experiences of the local community members to emerge, elucidating the role of international organizations in postconflict community development (Birks \& Mills, 2012; Charmaz, 2005).

This study analyzed two communities located in the Northern Provinces of the country, which were the last rebel stronghold, experienced the greatest effects of the conflict, and were the most recent to receive aid. Each community had active chapters of a local community education group, which helped to coordinate research efforts. This community-based group provided a local host who served as a co-researcher (Glesne, 2006), and helped translate, assist in data collection, and in purposive and snowball sampling (Birks \& Mills, 2012; Patton, 2002).

Purposive sampling is important in grounded theory methods, as it serves to help identify sources that are relevant to the area of study (Birks \& Mills, 2012). In this study, purposive sampling was used in each of the communities to create an initial pool of participants with varying demographics and experiences of postconflict community development. With limited scholarly knowledge in the area, considering community demographics allowed for a variety of perspectives. This, however, did not hinder the iterative nature of exploring emerging theories and themes through snowball sampling (Bryant \& Charmaz, 2007; Patton, 2002) as the process of interviewing, transcribing, and coding progressed. Overall, the 28 participants (all names herein are pseudonyms) included more women and youth (considered those under 35 in Sierra Leone), due to the disproportionate death toll of men during the war, and those with various 
Running Head: COMMUNITY TRANSITION IN SIERRA LEONE

degrees of education and formal power within the communities. Included were four community chiefs and elders, four skill-based tradespeople, one school principal, two political officials, one religious leader, two individuals working in community development, seven farmers or microbusiness people, and seven individuals who were currently in school, skills training programs, or were not working. Participant ages ranged from early 20s to above 60 years old.

Interviews were digitally recorded and all were transcribed verbatim, with transcription checking and clarification from the local co-researchers. Real time transcription enabled the interviews of the next participants to be reflective of emerging ideas and data; the iterative process of theoretical sampling being a key element to grounded theory research methods (Birks \& Mills, 2012). Transcripts were analyzed using focused coding and inputted into a digital platform. Codes were then built into categories and emergent themes, discussed in detail below. The analysis of the relationship of these themes contributed to the theory development. Therefore, due to the both the structure and flexibility of grounded theory, and the emergent nature of data collection and analysis, this central theoretical argument was revealed (Charmaz, 2005): Community members' regard of the work of international organizations lessens as these efforts transition from relief efforts and securing the peace to aid for development.

It is important to note that the community members who were best versed in the work of international organizations were those with more power in the community, such as political leaders, leaders of community groups, and educators, and had a better command of English. Overall, 25 of the 28 (89\%) participants spoke about international organizations, and 15 out of these 25 (60\%) discussed the contributions of these organizations at length. This indicates that there was a range in the capacities of participants to analyze the work of the international organizations based on level of education, political, or career achievement and that those with 
Running Head: COMMUNITY TRANSITION IN SIERRA LEONE

power and education drive the study data. Those with limited access to power and education may have had lesser access to, support from, or information about the efforts of international organizations indicating a potential lack of inclusivity in the communities. A complimentary study by M’Cormack-Hale (2013) also found those with exposure to international organizations tended to have higher levels of political awareness. This participant power and educational dynamic should be considered in reviewing the findings of the study.

\section{Findings}

International organizations provided postconflict assistance in Sierra Leone by supplying services, goods, and relief efforts at the end of the civil conflict and then shifting efforts to development activities. The findings discussed below shed light on community experiences during both of these periods by discussing the role of international organizations in securing the peace and relief efforts, and then assistance with development projects, in terms of building of infrastructure and other community-specific development projects. In each area, the perceived benefits will be discussed first, followed by perceived challenges. Despite data collection in 2009, the findings are currently relevant as over half of the government budget still comes from bilateral and multilateral investors (UNDP, 2018) and several years of community development efforts were challenged by the immediate need of the Ebola crisis.

Securing the peace. Toward the end of the war, The Economic Community of West African States Monitoring Group (ECOMOG) and The United Nations Mission in Sierra Leone sent peacekeeping troops to assist Sierra Leone in securing the peace. Community members credited these groups for their work in ending the war, and for “...preaching peace [so that] people had confidence, would not be afraid, [and] return [back to the communities]” (Sinead, personal communication, June 4, 2009). The UN and other international organizations did this by 
Running Head: COMMUNITY TRANSITION IN SIERRA LEONE

“...call[ing] meetings for peace... and help[ing] to maintain the peace... There were lots of meetings to help maintain the peace by [international organizations] and the local [chiefs] to talk to the rebels and the community” (Florence, personal communication, 2009). These meetings “... [brought] the community and the rebels together... [they] worked hand in hand; the people came back because they were confident” (Sinead, personal communication, June 4, 2009).

Uniting community groups was one of the most helpful ways the UN assisted in securing the peace, particularly with DDR. These programs “...took the weapons away from the rebels” (Sinead, personal communication, June 4, 2009) and “...gave them money for the guns, and resettlement packages” (Florence, personal communication, June 9, 2009). “The UN opened vocational institutions for ex-combatants to teach [them] skills, like carpentry and driving” (Sinead, personal communication, June 4, 2009), as well as “...local skills... and masonry” (Florence, personal communication, June 9, 2009). These programs were important so that the rebels “...[would] not harm civilians anymore. This [was] helpful because once they [had] jobs it [was] easier for [everyone] to all live together” (Sinead, personal communication, June 4, 2009).

In addition to DDR, “The rebels and the UN, together with the community, organized dancing and football matches, [which] brings peace and unity so people can live together well” (Sinead, personal communication, June 4, 2009). Other organizations “...organized activities like peace festivals, healing meetings, and field trips. They even undertook, to some extent, youth projects because the youth factor was a problem with this country--and still is a problem because most combatants are in this category” (Banura, personal communication, June 8, 2009).

Therefore, the community members often praised the international organizations for bringing peace to the communities and sustaining the peace through activities that connected divided peoples and provided training programs for ex-combatants. Not everyone saw these efforts as 
Running Head: COMMUNITY TRANSITION IN SIERRA LEONE

beneficial, however. As one participant stated, "People talked about a lot of things like DDR programs after the war, but these programs only cared about those that are rebels, not the local people” (Karamoh, personal communication, May 30, 2009). There was a sense that the rebels received more assistance than the civilians, who had not been perpetrators during the war.

Relief efforts. Local participants also praised the relief efforts of international organizations. These organizations provided food products, mainly rice, at the end of the conflict, which was important, as during the war, "There was no food, no markets, no farming to be done because [there were] no seed[s]” (Sahr, personal communication, May 28, 2009). The majority of participants stated that they received some assistance in terms of food and resources, which were necessary, because, “The perfect thing would be food for everyone to eat” (Sahr, personal communication, May 28, 2009), because during the war "In all the villages there [was] no food for those that were left” (Arif, personal communication, June 7, 2009). Little criticism was offered in terms of receiving necessary relief from the international organizations, as having basic needs met allowed for a focus on secondary needs, such as community development.

Aid for development. After the initial work of securing the peace and providing relief, international organizations' efforts transitioned to aid for development activities. These activities focused largely on the destroyed infrastructure and the need for community development projects. Participants discussed, at length, the benefits and challenges these efforts.

Infrastructure development. In addition to necessities such as food, international organizations also provided resources to build houses and community buildings, largely destroyed during the conflict. According to Rosaline (personal communication, June 2, 2009), a community leader, "[International organizations] built a lot of houses for the amputees; those who were affected during the war.” Other community members stated that these groups also built 
Running Head: COMMUNITY TRANSITION IN SIERRA LEONE

housing for the blind and constructed schools, health centers, and clinics. Further, international organizations provided resources for the construction of wells for safe drinking water. Each of these were important for communities “... to come together again” (Florence, personal communication, June 9, 2009).

In addition to building schools and health centers, international organizations also provided supplies and services for both. For schools, these organizations “...paid for fees for children and supplied almost everything” (Tenneh, personal communication, June 4, 2009), including “...constructing... benches and desks” (Florence, personal communication, June 9, 2009). The international organizations provided “...a lot of scholarships to people for schoolchildren” (Rosaline, personal communication, June 2, 2009). This assistance was particularly important “...because the schools were shut down during the war” (Florence, personal communication, June 9, 2009).

Plan International had a Children’s Rapid Education Project that served ...the children who [were] over-aged [for traditional school]. This group encourage[d] children to go to school, [and] instead of six years [of] primary [school], they do it in three years so that they can educate more children through the school system. Children in school have a common interest and it teaches them to do it as a community, and these things make them come together. It helps them get back and learn to do things as a group. (Suzan, personal communication, June 4, 2009)

There were also vocational institutions set up by international organizations that assisted in adult education where “...[people] could learn to use their hands... [because] the war took such a long time that some of the children could not go to school or were over age to go to school" (Suzan, personal communication, June 4, 2009). Schooling was important in the communities, 
Running Head: COMMUNITY TRANSITION IN SIERRA LEONE

because when “...schools were opened and training programs started... people came back to bring their children to school” (Tenneh, personal communication, June 4, 2009).

In addition to schools, participants stated that international organizations provided medicine and medical supplies, created health programs, and “...[taught] issues of health and hygiene in the schools--what to do to keep clean” (Florence, personal communication, June 4, 2009). In one community, Action Pharm “...opened a health care center in town, and admitted mothers and children there” (Tenneh, personal communication, June 4, 2009). They also “...gathered malnourished children from the bush and helped them become nourished” (Mark, personal communication, June 8, 2009). Participants also credited international organizations with building inner-country roads, and bringing clothing, blankets, utensils, building materials for small projects, and other necessary supplies to the communities.

Community development projects. Another way international organizations contributed was by funding community-driven development projects. Engaging with international organizations in these projects were important because “...the community [was] trying to find ways to develop itself, but they have no source for getting help” (Banura, personal communication, June 8, 2009). Therefore, the international organizations were helping to “...do things [the community] could not do by themselves” (Suzan, personal communication, June 4, 2009).

These development projects often included assistance with agricultural initiatives, where international organizations gave “...seeds so [that community members] could share with their neighbors” (Suzan, personal communication, June 4, 2009). “[International organizations] also help[ed] the communities to make seed banks. They help[ed] the people to save the seeds...at the end of the dry season they go and collect their seeds and plant” (Suzan, personal communication, June 4, 2009). Another project provided small business micro-loans “...usually [for] selling 
Running Head: COMMUNITY TRANSITION IN SIERRA LEONE

articles in the market,” which people “...had to pay back after one year” (Suzan, personal communication, June 4, 2009). Yet others saw these loans as “...good for any business [and] flexible. The [international organizations] support and guide you; and you gain for your family” (Tenneh, personal communication, June 4, 2009).

A large area of work, however, was funding the building of community-based structures. In some cases, “The chief call[ed] frequent meetings to make plans for the development of the [communities]. The chief talk[ed] with the national government and the international [organizations] (Tenneh, personal communication, June 4, 2009). In other cases, “[International organizations] call[ed] the chief and people together and [the] people give suggestions for development” (Zaria, personal communication, June 5, 2009).

Oftentimes, these development projects included the building of “...community huts where people could meet together... [When] communities could not have built their own huts, the [international organizations] supplied the things that the community could not get” (Suzan, personal communication, June 4, 2009), such as “...the local materials, like stones, [were] provided by the community, and the imported materials, like cement zinc, and nails [were] brought by the [international organizations]. They also [paid] the skilled laborers, but the communities provide[d] the unskilled labor” (Banura, personal communication, June 8, 2009). The international organizations “...[gave] money, and the local people implement[ed]” (Alie, personal communication, June 6, 2009).

In building, the local people are involved and the international [organizations] donates. It is done the way the local people want it done, but the international [organizations] monitors. If they could not have the international [organizations] the schools would not be built; the international [organizations] do not dictate; they talk to local people. They use local material, 
Running Head: COMMUNITY TRANSITION IN SIERRA LEONE

unskilled labor, and the people show them the sites. Sometimes they have to negotiate but the local people are happy, if [they] don't have community center they will build [one] for you, but then the people wanted to be involved so they had ownership and put in their input. (Alie, personal communication, June 6, 2009)

Challenges to infrastructure and community developmental projects. Not everyone agreed that the local people were happy with these arrangements, however. According to a community educator, Banura (personal communication, June 8, 2009),

International organizations bring expatriates to do the jobs, [and] this is a burning issue. Most of these jobs could be done by Sierra Leoneans. They could employ the Sierra Leoneans as members of their staff to help; they could have more local people ... [but] the [international organizations] come with expats and take the bulk of the work ... the communities [just] provide the unskilled labor.

Therefore, it is important to note the disagreement in the level of local buy-in in these projects. While some felt the international organizations could work out differences between their work and the local people’s ideas and beliefs, others felt as though local participation was stymied. The funding for the community-driven building was important, but there were questions around the relationships established in these efforts.

Another criticism of these development projects was around unfulfilled promises, often in terms of funding or resources. Community members discussed promises for resources that would not materialize, “[International organizations] say they want to help... but then get driven away to another area or country maybe. [The communities] want to develop, but are afraid to commit to something just for it to be taken away” (Ishmael, personal communication, May 29, 2009). 
Running Head: COMMUNITY TRANSITION IN SIERRA LEONE

Ishmael (personal communication, May 29, 2009) further articulated this fear by sharing a story about the Africa Mineral Group, a mineral exploration company,

This group wanted to create jobs in our area. So [the community] gave [them] a list of workers, but no mining of iron ore ever took place. [The organization] wanted to give the jobs so that people would not have to sit idle and do nothing, [but the community] does not know when the group is coming, it could be soon, or it could be far away.

Florence (personal communication, June 9, 2009) agreed, stating, “...programs come and go for a while, but then they just stop.” This left community members feeling disappointed when the organizations pulled resources, limited local opportunities, and did not fulfill their promises.

Despite these important challenges, overall the international organizations’ assistance with infrastructure and community-driven building efforts were important to development as they “...made [the community] work together and gave them ownership, [so] they would not destroy [the community buildings]” (Suzan, personal communication, June 4, 2009). The joint efforts between the local people and the international organizations was “...how the communities [got] involved and [took] part in the experience” (Banura, personal communication, June 8, 2009). The international organizations provided opportunities for development within the communities.

Overall, international organizations supported postconflict community development with aid, resources, supplies, construction, infrastructure, and community building. Participants felt that many of these efforts were essential for survival after the war. This work was not without challenges, however, including the trouble of relying so heavily on international organizations and being unsure of their commitment, both short- and long-term, to postconflict community development. Therefore, it is essential to understand the role on international organizations in postconflict community development in terms of both contributions and challenges. 
Running Head: COMMUNITY TRANSITION IN SIERRA LEONE

Interestingly, the challenges raised by the community members were far less in the areas of securing the peace and relief efforts than in the development projects. This raises an important question in the perceived regard for the work of international organizations in the period of securing the peace and relief efforts as compared to the transition of these organizations into the work of aid and development. A further discussion of this question appears below.

\section{Discussion and conclusions}

The findings indicate a complex relationship between international organizations and local Sierra Leone community members. Initially, international organizations granted aid and assistance in securing the peace and relief efforts, including providing resources and community programming directly after the conflict. Overall, local community members praised these efforts and appreciated the support to begin the recovery process. The primary challenge raised to this aid and assistance work was around a focus on perpetrators over victims. This critique is not unique to the communities studied, as literature has also criticized DDR projects (USAID, n.d.).

After a period of aid and assistance focused on securing the peace and relief efforts, international organization efforts transitioned to contributing to infrastructure and communitydriven development as is common in postconflict contexts (Bah, 2013). While some community members did praise the efforts of international organizations in this area as well, there were notable challenges expressed by participants. Community members in particular criticized the methods by which these international organizations operated--some community members felt as though there should be more support and use of expertise of local community members, promises made should be fulfilled, and programs and presence should not contribute to ongoing troubles. Overall, these findings serve to augment some of the literature that has focused on the need for international organizations to build more local buy-in and be more inclusive in 
Running Head: COMMUNITY TRANSITION IN SIERRA LEONE

programming (AFREX, 2007; Bah, 2013; Bolten, 2014; Chenge, 2002; Cubitt, 2012; Fanthorpe, 2003; Freeman, 2008; M’Cormack-Hale, 2010, 2013; Olonisakin, 2008; USAID \& UNDP, 2002).

This study contributes to this understanding by revealing the space where community support may have shifted, as data analysis revealed that community members' regard of the work of international organizations lessened as these efforts transitioned from securing the peace and relief to resources for development. This shift is important for understanding the role and relationship of international organizations in postconflict aid and development. It is possible that community members perceived international organizations’ securing the peace and relief efforts as more effective as these methods are, overall, fairly universal--rather than context-specific. In the immediate aftermath of a conflict, international organizations are often poised and ready to intervene (Mlambo, et. al., 2009) and provide opportunities for community members to come together to discuss peace and impact of peace on their community, and ways for the rebel and civilian groups to reconcile. While the efforts would occur at the local community level, across varying contexts and postconflict countries, this work might be similar (USAID \& UNDP, 2000).

As communities become more peaceful and begin to build anew, however, needs change. This is when international organizational assistance transitions from relief efforts and securing the peace to aid for community development. These efforts, then, become much more context-, and even community-, specific. It is here that there is an increased criticism of these efforts. Accommodating diverse sets of needs may become more difficult for the international organizations, thus raising space for disconnection with local community members.

It is clear that this transition space is an important area in the relationship between international organizations and local communities that needs to be explored further for 
Running Head: COMMUNITY TRANSITION IN SIERRA LEONE

development efforts to be more effective for both the communities and the international organizations. Although McIntyre Miller and Harter (2015) discussed the concept of liminality in terms of the Sierra Leonean chieftaincy, rather than community development, perhaps the concept is also applicable here: there is a liminal space provided as the relationship between international organizations and communities transitions from a period of relief to development. Critical to the success of development may be what can occur in the relationship between international organizations and local communities in this transitional, liminal space. Exploring this shift in space and effectiveness may further increase the understanding of how international organizations can better aid development of postconflict communities. The discussion below highlights implications of understanding and better addressing this transitional space for international organizations, postconflict communities, and communities from other contexts.

Implications for international organizations. For international organizations, the transitional space from relief efforts to community development is essential, as the work of the organization shifts from being broad-based in peace building techniques to that, which is context- and community-specific. It is in this space that a locally grounded relationship may be built to better ensure community buy-in and participation. Healthier communication between international organization staff and community leaders and members, including a thorough understanding of development promises, and a better appreciation of community desires and needs, could help foster this relationship. Hiring and maximizing local staff and labor with community-sensitive wages (Bolten, 2014) could also improve this relationship, as would providing rationale for the use of non-local labor and staff when necessary or appropriate.

It will also be imperative for international organizations to address their postconflict programming to ensure equality for all participants (Fanthorpe, 2003; USAID, n.d.). If there is 
Running Head: COMMUNITY TRANSITION IN SIERRA LEONE

inequities, efforts could be made to better serve the omitted population in the transition period between relief and development. In addition, prior to providing aid resources and programming, international organizations might consider more equitable programming.

Overall, international organizations provide a tremendous service to postconflict communities as they strive to build and recover from conflict. Focusing on the transitional space between relief and resources, rather than switching between efforts with limited attention to this liminal space, may serve to augment the relationship between these organizations and the communities to provide a positive, locally-driven development experience.

Implications for postconflict communities. Although postconflict, local communities are often at their weakest when assistance arrives from international organizations, these communities play a greater role as aid transitions from relief to development. The involvement of the community chiefs are essential for community buy-in and participation, even though there are challenges to the inclusion and responsiveness efforts of chiefs throughout the country (McIntyre Miller, 2013; M’Cormack-Hale, 2010; 2013). Despite these challenges, the chiefs may serve as a bridge between the international organizations and the community to help increase local participation and facilitate further local involvement in these projects, particularly as these projects shift from aid to development. Community members may connect with international organizations themselves as they begin the development phase to find their own ways to share concerns and express interest in being a part of the development efforts.

In many ways, a reciprocal relationship is essential for successful postconflict community development in Sierra Leone and in other similar contexts. Local communities rely on international organizations for aid and supplies immediately after a conflict and for development opportunities as they begin to recover. International organizations provide this aid, and serve to 
Running Head: COMMUNITY TRANSITION IN SIERRA LEONE

help growth and development. Operating in varying cultures and contexts can prove challenging to international organizations as they transition toward development, and therefore, connecting deeply with local community members may help to ensure community needs are being met.

Implications for other communities. The ideas discussed herein can also be relevant to communities in a variety of contexts. Communities engaging in development work often interact with outside organizations or groups and some of the rifts that emerge in these relationships may be similar. This is particularly true when the external group operates goals and outcomes that are not community-specific. As these relationships evolve, it is important to find the space to engage community voices, particularly encouraging external organizations to listen to local leaders in conveying community goals and needs and filling these with local capacity. Finding an early and clear fit between the community and the external organization may enhance joint endeavors.

Overall, the lessons from this study demonstrate that the transitional space that occurs as international organizations shift from relief efforts to resources for community development is important to consider and to further research. After this space, the work becomes more contextspecific, and therefore a connection between outside organizations and local communities should be developed to facilitate the collective work of development. Augmenting community connection at this point may be an important way for organizations to better interact with community, and community needs, for positive, postconflict development that promotes sustainable peace.

\section{References}

Abraham, A. (2001). Dancing with the chameleon: Sierra Leone and the elusive quest for peace. Journal of Contemporary African Studies, 19, 205-228.

Alie, J. (1990). A new history of Sierra Leone. New York, NY: St. Martin’s Press. 
Running Head: COMMUNITY TRANSITION IN SIERRA LEONE

Bah, A. B. (2013). The contours of new humanitarianism: War and peacebuilding in Sierra Leone. Africa Today, 60, 3-26.

Bah, A. S. (2012). Sierra Leone. In R. Caplan (Ed.) Exit strategies and state building (pp.100117). Oxford, UK: Oxford University Press.

Baker, B., \& May, R. (2006). A sustainable peace? Sierra Leone. In O. Furley \& R. May (Eds.), Ending Africa’s wars: Progressing to peace (pp. 221-237). Hampshire, England: Ashgate Publishing Limited.

Binns, T., \& Maconachie, R. (2005). 'Going home’ in post-conflict Sierra Leone: Diamonds, agriculture and re-building rural livelihoods in the Eastern Province. Geography, 90, 67-78.

Birks, M., \& Mills, J. (2012). Grounded theory: A practical guide. London, UK: Sage.

Bolten, C. (2014). Social networks, resources, and international NGOs in postwar Sierra Leone. African Conflict and Peacebuilding Review, 4, 33-59.

Bryant, A., \& Charmaz, K. (2007). The Sage handbook of grounded theory. London, UK: Sage.

Burde, D. (2004). Weak state, strong community? Promoting community participation in postconflict countries. Current Issues in Comparative Education, 6(2), 73-87. Retrieved https://files.eric.ed.gov/fulltext/EJ853840.pdf

Carver, R. (1997). Sierra Leone: From cease-fire to lasting peace? United Nations High Commission for Refugees. Retrieved from https://www.refworld.org/docid/3ae6a6b624.html Charmaz, K. (2005). Grounded theory: Methods for the $21^{\text {st }}$ century. Thousand Oaks, CA: Sage. Chenge, M. (2002). Sierra Leone: The state that came back from the dead. The Washington Quarterly, 25, 147-160.

Cubitt, C. (2012). Local and global dynamics of peacebuilding: Post-conflict reconstruction in Sierra Leone. Oxon, UK: Routledge. 
Running Head: COMMUNITY TRANSITION IN SIERRA LEONE

Curran, D. \& Woodhouse, T. (2007). Cosmopolitan peacekeeping and peacebuilding in Sierra Leone: What can Africa contribute? International Affairs, 83, 1055-1070.

Fanthorpe, R. (2003). Humanitarian aid in post-war Sierra Leone: The politics of moral economy. In S. Collinson (Ed.), Power, livelihoods and conflict: Case studies in political economy analysis for humanitarian action (pp. 53-66). London, UK: Overseas Development Institute.

Fanthorpe, R. (2004). Post-war reconstruction in rural Sierra Leone: What political structures may prove viable? Sussex, UK: UK Department for International Development.

Fanthorpe, R. (2005). On the limits of liberal peace: Chiefs and democratic decentralization in post-war Sierra Leone. African Affairs, 105(418), 27-49.

Freeman, C. (2008, March). The failures of post-conflict reconstruction in Sierra Leone and the threat to peace. Retrieved from the Beyond Intractability website: https://www.beyondintractability.org/casestudy/freeman-failures

Glentworth, G. (2002). Post-conflict reconstruction: Key issues in governance. A preliminary discussion paper. Retrieved from the United Kingdom Department for International Development website: http://www.gsdrc.org/docs/open/SS13.pdf

Glesne, C. (2006). Becoming a qualitative researcher. Boston, MA: Pearson Education.

Hanlon, J. (2005). Is the international community helping to recreate the pre-conditions for war in Sierra Leone? The Round Table: The Commonwealth Journal of International Affairs 94(381), 459-472.

Hutchful, E. (2012). Security sector governance and peacebuilding. In D. Curtis \& G.A. Dzinesa (Eds.), Peacebuilding, power, and politics in Africa (pp. 63-86). Athens, OH: Ohio University Press. 
Running Head: COMMUNITY TRANSITION IN SIERRA LEONE

Jackson, M. G. (2005). A necessary collaboration: NGOs, peacekeepers and credible military force - the case of Sierra Leone and East Timor. In O.P. Richmond \& H.F. Carey (Eds.), Subcontracting peace: The challenges of NGO peacebuilding (pp. 109-118). Burlington, VT: Ashgate Publishing.

Kaplan, J. (2013). ‘Reading’ British armed humanitarian intervention in Sierra Leone 2000-2. In B. Everill \& J. Kaplan (Eds.), The history and practice of humanitarian intervention and aid in Africa (pp. 93-119). Hampshire, UK: Palgrave McMillan.

Karns, M. P., Mingst, K. A., \& Stiles, K. W. (2015). International organizations: The politics and processes of global governance. Boulder, CO: Lynne Rienner Publishers.

Keen, D. (2005). Conflict and collusion in Sierra Leone. New York, NY: Palgrave.

Keen, D. (2008). Complex emergencies. Cambridge, UK: Polity Press.

Khadiagala, G. M. (2012). The role of the African Union, New Partnership for Africa’s Development, and African Development Bank in postconflict reconstruction and peacebuilding. In D. Curtis \& G.A. Dzinesa (Eds.), Peacebuilding, power, and politics in Africa (pp. 107-120). Athens, OH: Ohio University Press.

King, D. (2005). Parallel routes to recovery: Community priorities and NGO policy in the post civil war reconstruction of Sierra Leone. International Journal of Emergency Management, 2, 149-153.

Leff, J. (2008). The nexus between social capital and reintegration of ex-combatants: A case for Sierra Leone, African Journal on Conflict Resolution, 8, 9-38. Retrieved https://www.ajol.info/index.php/ajcr/article/viewFile/39419/29626

Manning, R. (2009). Exploitation of poor communities in Sierra Leone: False promises in reconstruction and development. Justice and Development: Working Paper Series 1(3), 4907. 
Running Head: COMMUNITY TRANSITION IN SIERRA LEONE

Masin-Peters, J. (2003). Conflict diamonds. Retrieved from http://pawss.hampshire.edu/topics/ conflictdiamonds/index.html

M’Cormack-Hale, F. A. O. (2013). Partners or adversaries? NGOs and the state in postwar Sierra Leone. In C. R. Veney, \& D. W. Simpson. African democracy and development: Challenges for post-conflict African nations (pp. 137-154). Lanham, MD: Lexington.

M’Cormack-Hale, F. A. O. (2010). The role of NGOs in the democratization process in postwar Sierra Leone. In M. Mustapha, \& J. Bangura (Eds.) Sierra Leone beyond the Lomé Peace Accord (pp. 97-116). New York, NY: Palgrave MacMillan.

McIntyre Miller, W. (2010). Postconflict community development in Sierra Leone: Western, cultural, and national influences (Unpublished doctoral dissertation). University of San Diego, San Diego, CA.

McIntyre Miller, W. (2012). Moving forward in Sierra Leone: Community-based factors for postconflict development. Community Development: Journal of the Community Development Society, 43, 550-565.

McIntyre Miller, W. (2013). Chieftaincy-based community dispute resolution: The case of Sierra Leone. Conflict Resolution Quarterly, 30, 295-308.

McIntyre Miller, W., \& Harter, N. (2015). Liminality and community leadership: Transitioning leadership in postconflict in Sierra Leone. International Leadership Journal, 7(1), 3-22. Retrieved from http://www.tesc.edu/documents/ILJ_Winter_2015.pdf

Mlambo, M., Kamara, A., \& Nyende, M. (2009). Financing post-conflict recovery in Africa: The role of international development assistance. Journal of African Economies, 18, i53-i76.

Olaleye, W. \& Backer, D. (2005). Promoting NGOs as agents of social stabilization: Trauma management and crime prevention initiatives in the Southern Africa region. In O. P. 
Running Head: COMMUNITY TRANSITION IN SIERRA LEONE

Richmond \& H. F. Carey (Eds.) Subcontracting peace: The challenges of NGO peacebuilding (pp. 143-154). Burlington, VT: Ashgate Publishing.

Olonisakin, 'F. (2008). Peacekeeping in Sierra Leone: The story of UNAMSIL. Boulder, CO: Lynne Rienner Publications.

Patton, M. (2002). Qualitative research and evaluation methods. Thousand Oaks, CA: Sage. Pham, J. P. (2006). The Sierra Leone tragedy: History and global dimensions. New York, NY: Nova Science Publishers, Inc.

Rogers, J. (2006, January 18). Challenges to post-war economic reconstruction: A case study of Sierra Leone. Speech given at the "War Don Don” $4{ }^{\text {th }}$ Anniversary, Freetown, Sierra Leone. Sriram, C.L. (2011). (Re)building the rule of law in Sierra Leone: Beyond the formal sector? In C.L. Sriram, O. Martin-Ortega, \& J. Herman (Eds.) Peacebuilding and rule of law in Africa: Just peace? (pp. 127-141). Oxon, UK: Routledge.

UNDP (2018). Aid coordination and poverty reduction. Retrieved from http://www.sl.undp.org/ content/sierraleone/en/home/operations/projects/poverty_reduction/aid-coordination-andpoverty-reduction.html

UNDP. (2006, February). Post-conflict reconstruction of communities and socio-economic development. Paper presented at the Tokyo International Conference on African Development Conference on Consolidation of Peace, Addis Abada, Ethiopia.

USAID. (n.d). Community-focused reintegration. Retrieved from http://pdf.usaid.gov/pdf_docs/PNADF305.pdf

USAID \& UNDP. (2000). Community-based reintegration and rehabilitation in post-conflict settings. Washington, DC: Meridian International Center. 
Running Head: COMMUNITY TRANSITION IN SIERRA LEONE

U. S. Department of State. (2008). Background note: Sierra Leone. Retrieved from http://www.state.gov/r/pa/ei/bgn/5475.htm\#history

World Bank. (n.d). Community-driven conflict recovery: From reconstruction to development. Washington, DC: The World Bank. Retrieved from http://siteresources.worldbank.org/ INTSF/Resources/395669-1126194965141/1635383-1154459301238/CDR-CDD.pdf 